\title{
The effect of fruit cultivar/origin and storage time on sorbets quality
}

\author{
Cátia Hipólito ${ }^{\mathrm{a}, \mathrm{b}}$, Rosário Ramalheira ${ }^{\mathrm{a}}$, Sara Beirão da Costa ${ }^{\mathrm{c}}$, \\ Margarida Moldão-Martins ${ }^{\text {b, * }}$ \\ ${ }^{a}$ Department Director of Food Quality and Safety, Santini - Estrada da Torre, Mercado de Carcavelos, 2775-687, Carcavelos, Portugal \\ ${ }^{\mathrm{b}}$ LEAF - Linking Landscape, Environment, Agriculture and Food, Instituto Superior de Agronomia, Universidade de Lisboa, Tapada da Ajuda, $1349-017$ \\ Lisboa, Portugal \\ c PROSENSE - INOVISA, Tapada da Ajuda 1349-017 Lisboa, Portugal
}

\section{A R T I C L E I N F O}

\section{Article history:}

Received 29 May 2015

Received in revised form

15 November 2015

Accepted 24 December 2015

Available online 29 December 2015

\section{Keywords:}

Sorbet

Fruit

Cultivar

Origin

Storage time

\begin{abstract}
A B S T R A C T
Fruit quality is one of the main factors that influence the sorbets' quality. The aim of this study was to evaluate the effects of two different cultivars of five fruits (mandarin, lemon, melon and mango) or origin (strawberries) on the overall quality of sorbets, right after being produced and after being preserved for 21 days at $-18^{\circ} \mathrm{C}$. Total soluble solids (TSS), titratable acidity (TA) and firmness were used to characterize the fruits. Colour, $\mathrm{pH}$, antioxidant capacity (AC) and total phenolic content (TPC), as well as sensory attributes, were evaluated on fruits and respective sorbets. Fruit processing led to a loss of TPC and AC Nevertheless, no significant changes were observed on sorbets over storage time. In spite of chemical, physical and sensorial differences registered among fruits from different cultivars or origin, the sensory profiles of sorbets from the same pair of studied fruits are very similar.

Multivariate analysis clearly shows that the sorbets produced maintain the same sensorial quality regardless of the cultivar or the origin of the fruits.
\end{abstract}

(c) 2016 Elsevier Ltd. All rights reserved.

\section{Introduction}

Sorbets are frozen desserts essentially made of water and sugar, with a fruit content of at least $25 \%$. No fat substances should be added (Goff \& Hartel, 2013), or any chemical agent that increases or accelerates the production process. The cultivar, origin and ripeness degree of fruits are the factors that most influence the fruit quality and derivative products, such as sorbets. There are several examples of such influence on pears (Markowski, Zbrzezniak, Mieszczakowska-Frac, Rutkowski, \& Popinska, 2012), mandarins (Simón-Grao et al., 2014), mangos (Ngamchuachit, Sivertsen, Mitcham, \& Barrett, 2015) and melons (Botia, Navarro, Cerdá, \& Martınez, 2005).

The processing of sorbets is characterized by the incorporation of small amounts of air, making it a dispersion of ice crystals randomly distributed in a freeze-concentrated liquid phase (Corvitto, 2005). Small ice crystals are desired to deliver a product with a smooth texture and good palatability (Arellano, Benkhelifa,

\footnotetext{
* Corresponding author.

E-mail addresses: mmoldao@isa.utl.pt,mmoldao@isa.ulisboa.pt (M. MoldãoMartins).
}

Flick, \& Alvarez, 2012; Corvitto, 2005).

Representing approximately $90 \%$ of the final product, fruit takes the role of main ingredient, being crucial to ensure the highest quality of this raw material. Its availability depends on the season, thus cultivar/origin used will not always be the same, which may influence the physical, chemical and sensory parameters of sorbets. Likewise, storage conditions of fruits, mainly time and temperature, are very important to achieve high quality sorbets (Corvitto, 2005). At the reception, fruits should be at an ideal ripening stage and must not have any injury.

Mango (Mangifera indica L.) is a popular and economically important tropical fruit throughout the world, due to its excellent eating quality (bright colour, sweet taste and luscious flavour) and nutritional composition (vitamins, minerals, fibres, and phytochemicals) (Kim, Lounds-Singleton, \& Talcott, 2009). Mango is considered to be a source of antioxidants including ascorbic acid (mangos provide about $50 \%$ of the recommended daily intake of vitamin C) and carotenoids. The best quality of mango fruits should be achieved with a 50\% green and 50\% red colouration and its "shoulders" ought to be above the insertion of the stalk region and its "cheeks" rounded.

Melon (Cucumis melo L.) is one of the most consumed and appreciated fruits. The quality attributes of melon mainly depend on 
the genotype, maturity stage and storage temperature. Cantaloupe melons are low in energy but excellent sources of nutrients, in particular provitamin A and vitamin C (Lester, 2006). Cantaloupe and Ogeon (commonly designated by Gália) melons, belonging to Cantaloupensis group, are climacteric and fast senescing fruits and are very aromatic. Due to its highly appreciated sensory attributes, Gália melons are currently a potential raw material for the fresh cut or other fruit derivatives (Aguayo, Escalona, \& Artés, 2004), such as sorbets. Mature melons should present a hard and bright green peel and a firm and proper colouration of flesh at the moment of reception.

Strawberries (Fragaria $x$ ananassa Duch.) are widely consumed both fresh and processed. The overall quality of strawberries is mainly dependent on the genetic and environmental factors, ripeness and storage conditions (Tulipani et al., 2011; Shin, Ryu, Liu, Nock, \& Watkins, 2008). Harvesting at the right maturity stage is crucial for keeping optimal quality during storage and handling (Sturm, Koron, \& Stampar, 2003). In order to produce high quality sorbets, strawberries should have a medium size, firm texture and intense red colour.

Citrus fruits are non-climacteric fruits with low respiration and ethylene production rates and do not undergo any major softening or compositional changes after harvest (Kader, 1985). Citrus fruits are a good source of nutrients, including flavonoids, citric acid, vitamin $\mathrm{C}$ and minerals. In these fruits, colour is the most important parameter at reception, therefore orange and mandarin must have an intense orange colour, and lemon an intense yellow, both of all with a thin peel.

The present work was developed at a worthy artisanal industry of ice creams, the sorbets being premium products of the company. Having in mind that: (i) an ideal sorbet should maintain all the fresh fruit flavour characteristics, (ii) it is important to maintain the sorbet quality throughout the year, (iii) the fruit production is seasonal making it necessary to use different sources or cultivars of the fruits and (iv) the sorbets are stored at least for 21 days at $-18{ }^{\circ} \mathrm{C}$; the main objective of the present work was to study the effect of cultivar and/or origin and storage time on the overall quality of the sorbets.

\section{Material and methods}

\subsection{Fruits}

Six fruits from two different cultivars or origins, available in the Portuguese market, were selected as raw materials for sorbet manufacture: Mandarin (Citrus reticulate)-Encore (E) and Ortanique (O); lemon (Citrus lmon) - Eureka(Eu) and Lunário (Lu); orange (Citrus sinensis) -Navelate (N) and Lanelate (L); melon (Cucumis melo L. var. cantaloupensis Naud.)-Gália (G), and Cantaloupe (C); mango (Mangifera indica L.)-Palmer $(\mathrm{P})$ and Haden $(\mathrm{H})$ and Strawberry (Fragaria $x$ ananassa Duch) - Spain (Sp) and Portugal (Pt).

All fruits were purchased from a local market at the commercial ripening stage. Fruits were selected according to external skin colour, uniform size and absence of any physical damage. Sampling of fruits occurred randomly upon reception.

\subsection{Sorbet production}

Sorbets processing operations were carried out according to Fig. 1. The processing operations were the same for every fruits. The recipe was adjusted according to each fruit category independently of cultivar or origin, taking into account the TSS, defined by the company's (Santini) quality department.

Temperature lowering is one of the most important steps. At this stage temperature is lowered from $4{ }^{\circ} \mathrm{C}$ to $-11^{\circ} \mathrm{C}$, under stirring and cooling by contact, over $20 \mathrm{~min}$, approximately. From this moment, the stirring system allows an incorporation of air and the distribution of small air bubbles throughout the mixture is observed. The cooling process is fast until the temperature reaches $-6{ }^{\circ} \mathrm{C}$, lowering thereafter, once the freezing temperature is becoming lower due to the rise of soluble solids concentration. Since the sorbet is an unstable product as it contains a considerable amount of free water, the stabilizing step must performed as quickly as possible. As such, sorbet is stored in a cold storage room for the thermal centre to reach temperatures about $-18{ }^{\circ} \mathrm{C}$ as soon as possible, in order to prevent the formation of ice crystals, achieving its stabilization.

\subsection{Analytical procedures}

Analytical procedures were carried out at least in triplicate, on two sampling dates - after processing (day 1 ) and after 21 days of storage at $-18{ }^{\circ} \mathrm{C}$ (day 21 ).

\subsubsection{Total soluble solids, titratable acidity and $\mathrm{pH}$}

Total soluble solids (TSS) of fruits were determined by using a refractometer (Pocket Refractometer Pal-1 Atago).

Titratable acidity (TA) was measured by titration method with a standard solution of sodium hydroxide $(\mathrm{NaOH})$, by using an alcoholic solution of 1.0\% phenolphthalein as indicator (ISO 750:1998). Results were expressed in \% citric acid by the conversation factor in citric acid (vol. $\mathrm{NaOH}(\mathrm{mL}) \times$ 0.07). Sampling fruits was carried out in triplicate and acidity determination was carried out in duplicate.

A potentiometer (Denver Instrument Model 220) previously calibrated at $20^{\circ} \mathrm{C}$ with standard solution at $\mathrm{pH} 4.01$ and 7.0 was used to determined $\mathrm{pH}$ of fruits and sorbets samples.

\subsubsection{Firmness}

Firmness of fruits was measured with a penetrometer (Force Gauge PCE-FM 200). Sampling was carried out in triplicate and results were expressed in Newton $(\mathrm{N})$.

\subsubsection{Colour}

Colour measurements were performed with a colorimeter (Minolta Chroma Metre CR 300) by measuring the CIE L*a*b* parameters. The instrument was calibrated using a standard white tile $\left(\mathrm{L}^{*}=97.10, \mathrm{a}^{*}=0.19, \mathrm{~b}^{*}=1.95\right)$. Data was converted to C (Chromaticity) and oh (hue angle) according to the follow equations: $\mathrm{C}^{*}=\sqrt{\mathrm{a}^{* 2}+\mathrm{b}^{* 2}} ; \quad{ }^{\circ} \mathrm{h}=\operatorname{arctg}\left(\frac{\mathrm{b}^{*}}{\mathrm{a}^{*}}\right) \quad$ if $\quad \mathrm{a} *>0 ; b^{*}>0 \quad$; ${ }^{\circ} \mathrm{h}=180+\operatorname{arctg}\left(\frac{\mathrm{b}^{*}}{\mathrm{a}^{*}}\right) \quad$ if $\mathrm{a} *<0 ; \mathrm{b}^{*}>0 ; \quad{ }^{\circ} \mathrm{h}=270+\operatorname{arctg}\left(\frac{\mathrm{b}^{*}}{\mathrm{a}^{*}}\right)$, if $\mathrm{a} *<0 ; \quad \mathrm{b}^{*}<0$ and ${ }^{\circ} \mathrm{h}=360+\operatorname{arctg}\left(\frac{\mathrm{b}^{*}}{\mathrm{a}^{*}}\right)$ if $\mathrm{a} *>0 ; \mathrm{b}^{*}<0$ (Hunt, 2004; Sahin \& Sumnu, 2006).

\subsection{Total phenolic content}

Total phenolic content (TPC) was determined using the Folin-Ciocalteu reagent (Swain \& Hillis, 1959). Samples (5 g) were homogenized with methanol $(20 \mathrm{~mL})$ and left in the dark overnight at $4{ }^{\circ} \mathrm{C}$. Homogenates were centrifuged at $29000 \mathrm{~g}$ for $15 \mathrm{~min}$ at $4{ }^{\circ} \mathrm{C}$ and the clear supernatant (methanolic extract) was used for total phenolic content determination according to the method described by Swain and Hillis (1959). Methanolic extracts $(150 \mu \mathrm{L})$ were diluted with nanopure water $(2400 \mu \mathrm{L})$ in test tubes, followed by the addition of $0.25 \mathrm{~N}$ Folin-Ciocalteu reagent $(150 \mu \mathrm{L})$. The mixture was incubated for $3 \mathrm{~min}$, and then, $1 \mathrm{~N} \mathrm{Na}_{2} \mathrm{CO}_{3}(300 \mu \mathrm{L})$ was added. The final mixture was incubated for $2 \mathrm{~h}$ in darkness conditions at room temperature. Spectrophotometric readings at $725 \mathrm{~nm}$ were collected using an ATI Unicam UV/VIS 4 spectrophotometer (Unicam Sistemas Analíticos, Lisboa, Portugal). The extraction was 

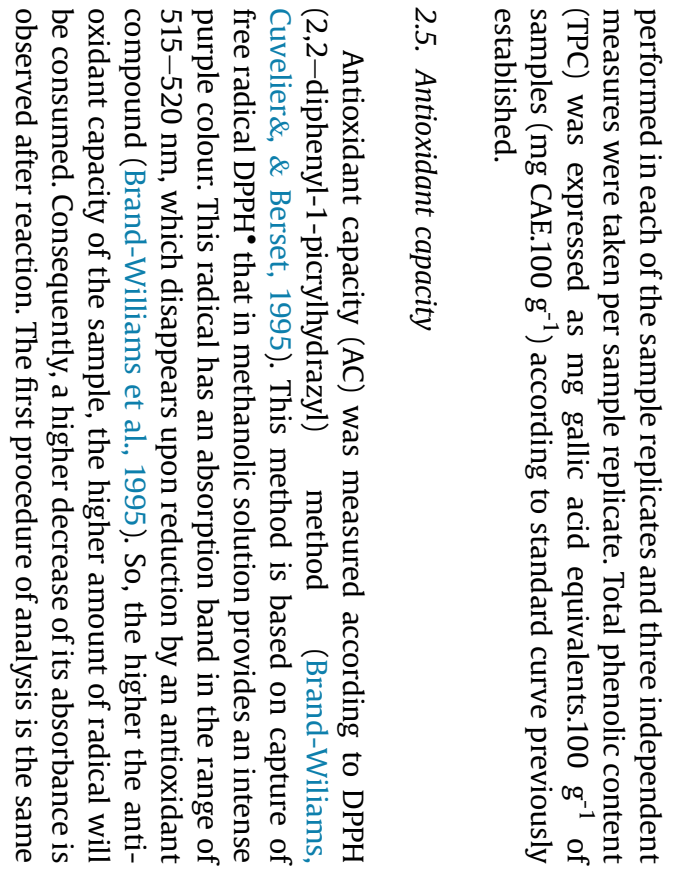

Physicochemical characteristics of the fruits.

\begin{tabular}{|c|c|c|c|c|c|c|c|c|c|c|c|c|c|}
\hline & & \multicolumn{2}{|l|}{ Mandarin } & \multicolumn{2}{|l|}{ Lemon } & \multicolumn{2}{|l|}{ Orange } & \multicolumn{2}{|l|}{ Melon } & \multicolumn{2}{|l|}{ Mango } & \multicolumn{2}{|l|}{ Strawberry } \\
\hline & & E & 0 & $\mathrm{Eu}$ & $\mathrm{Lu}$ & $\mathrm{N}$ & $\mathrm{L}$ & G & c & $\mathrm{P}$ & $\mathrm{H}$ & $\mathrm{Sp}$ & $\mathrm{Pt}$ \\
\hline \multicolumn{2}{|l|}{ TSS } & $11.9 \pm 0.4 a$ & $15.0 \pm 0.5 b$ & $6.5 \pm 0.3 a$ & $6.9 \pm 0.2 a$ & $12.8 \pm 0.6 a$ & $11.4 \pm 0.5 b$ & $9.4 \pm 0.8 a$ & $10.7 \pm 0.3 b$ & $14.8 \pm 0.3 a$ & $9.1 \pm 0.4 b$ & $6.4 \pm 0.2 a$ & $7.6 \pm 0.5 b$ \\
\hline \multicolumn{2}{|l|}{ TA } & $0.5 \pm 0.0 a$ & $1.1 \pm 0.0 b$ & $5.2 \pm 0.1 a$ & $5.4 \pm 0.1 b$ & $0.7 \pm 0.2 a$ & $0.7 \pm 0.2 a$ & $0.1 \pm 0.0 a$ & $0.1 \pm 0.0 a$ & $0.1 \pm 0.0 a$ & $0.2 \pm 0.0 b$ & $0.5 \pm 0.2 a$ & $0.5 \pm 0.1 a$ \\
\hline \multicolumn{2}{|c|}{ TSS/TA } & $26.3 \pm 2.1 a$ & $11.4 \pm 2.6 b$ & $1.3 \pm 0.0 a$ & $1.3 \pm 0.1 a$ & $20.3 \pm 5.3 a$ & $16.6 \pm 0.8 b$ & $150.9 \pm 73.7 a$ & $157.1 \pm 26.1 a$ & $119.2 \pm 14.4 a$ & $51.3 \pm 2.4 b$ & $14.7 \pm 4.9 a$ & $15.7 \pm 2.0 a$ \\
\hline \multicolumn{2}{|c|}{ Firmness } & $4.5 \pm 1.0 a$ & $13.7 \pm 3.0 b$ & $48.2 \pm 3.9 a$ & $48.7 \pm 2.6 a$ & $14.0 \pm 2.9 a$ & $8.6 \pm 4.6 b$ & $78.7 \pm 10.6 a$ & $62.2 \pm 21.9 a$ & $5.4 \pm 0.7 a$ & $7.2 \pm 1.6 b$ & $3.0 \pm 0.4 a$ & $3.6 \pm 0.4 a$ \\
\hline \multicolumn{2}{|c|}{$\mathrm{pH}$} & $4.2 \pm 0.0 a$ & $3.7 \pm 0.0 b$ & $2.6 \pm 0.0 a$ & $2.7 \pm 0.0 \mathrm{a}$ & $4.0 \pm 0.0 a$ & $3.9 \pm 0.0 b$ & $6.3 \pm 0.0 a$ & $6.5 \pm 0.0 b$ & $5.0 \pm 0.0 a$ & $4.7 \pm 0.0 b$ & $3.4 \pm 0.0 a$ & $3.5 \pm 0.0 b$ \\
\hline \multicolumn{2}{|c|}{ Moisture } & $83.9 \pm 0.0 a$ & $81.7 \pm 0.0 a$ & $93.6 \pm 0.1 a$ & $85.1 \pm 5.3 a$ & $78.3 \pm 0.0 a$ & $86.4 \pm 0.0 b$ & $92.0 \pm 0.1 a$ & $77.7 \pm 1.3 b$ & $86.0 \pm 0.2 a$ & $87.1 \pm 0.2 a$ & $91.9 \pm 0.2 a$ & $90.7 \pm 0.4 a$ \\
\hline \multicolumn{2}{|c|}{ TPC } & $198.0 \pm 14.4 a$ & $195.5 \pm 21.5 a$ & $764.8 \pm 90.8 a$ & $675.6 \pm 30.4 a$ & $228.0 \pm 25.6 a$ & $236.1 \pm 6.8 a$ & $55.1 \pm 6.4 a$ & $52.9 \pm 8.1 a$ & $810.7 \pm 28.2 a$ & $712.4 \pm 115.5 a$ & $1043.0 \pm 44.0 a$ & $1014.3 \pm 32.9 a$ \\
\hline & & $336.7 \pm 51.7 a$ & $434.4 \pm 15.6 a$ & $591.0 \pm 17.9 a$ & $520.0 \pm 28.6 a$ & $735.0 \pm 102.0 a$ & $656.8 \pm 90.9 b$ & $87.5 \pm 14.6 a$ & $100.9 \pm 14.2 a$ & $693.9 \pm 48.3 a$ & $633.5 \pm 11.4 a$ & $877.0 \pm 18.0 a$ & $897.5 \pm 2.8 a$ \\
\hline & $\mathrm{L}^{*}$ & $58.1 \pm 13.6 a$ & $70.9 \pm 7.1 a$ & $56.2 \pm 7.2 a$ & $69.9 \pm 5.2 b$ & $70.1 \pm 14.0 a$ & $66.2 \pm 13.4 a$ & $64.6 \pm 10.6 a$ & $47.2 \pm 2.8 b$ & $55.3 \pm 0.9 a$ & $65.7 \pm 1.6 a$ & $49.7 \pm 5.7 a$ & $52.5 \pm 4.4 a$ \\
\hline & C & $38.0 \pm 9.6 a$ & $39.9 \pm 10.0 a$ & $17.7 \pm 1.2 a$ & $12.4 \pm 1.5 b$ & $33.1 \pm 8.7 a$ & $35.6 \pm 6.5 a$ & $18.1 \pm 3.4 a$ & $23.0 \pm 5.7 b$ & $64.5 \pm 1.6 a$ & $67.3 \pm 1.9 b$ & $53.5 \pm 2.0 a$ & $61.4 \pm 2.6 b$ \\
\hline & oh & $91.1 \pm 4.3 a$ & $98.0 \pm 3.6 b$ & $100.1 \pm 2.2 a$ & $107.5 \pm 2.5 b$ & $100.5 \pm 4.2 a$ & $98.2 \pm 2.1 \mathrm{a}$ & $108.5 \pm 13.2 a$ & $85.0 \pm 1.1 b$ & $91.7 \pm 0.3 a$ & $88.0 \pm 0.7 b$ & $57.8 \pm 3.1 a$ & $62.0 \pm 1.9 b$ \\
\hline \multirow[t]{3}{*}{ Peel } & $\mathrm{L}^{*}$ & $65.5 \pm 4.2 a$ & $55.9 \pm 16.7 a$ & $71.4 \pm 3.1 a$ & $74.8 \pm 1.2 b$ & $68.5 \pm 3.5 a$ & $70.5 \pm 2.9 a$ & $66.9 \pm 2.5 a$ & $69.3 \pm 3.6 b$ & - & - & $38.6 \pm 3.1 a$ & $32.3 \pm 2.9 b$ \\
\hline & $\mathrm{C}$ & $60.6 \pm 4.4 a$ & $58.0 \pm 11.5 a$ & $57.9 \pm 5.1 a$ & $50.5 \pm 4.1 b$ & $69.0 \pm 2.6 a$ & $73.7 \pm 3.2 b$ & $34.3 \pm 7.1 a$ & $16.4 \pm 1.7 b$ & - & - & $35.3 \pm 4.2 a$ & $31.9 \pm 3.4 b$ \\
\hline & oh & $78.9 \pm 6.4 a$ & $64.9 \pm 18.7 b$ & $93.3 \pm 2.4 a$ & $98.2 \pm 1.2 b$ & $79.2 \pm 2.9 a$ & $80.6 \pm 2.7 a$ & $93.2 \pm 1.5 a$ & $101.0 \pm 2.8 b$ & $83.0 \pm 7.59 a$ & $54.5 \pm 3.7 b$ & $37.4 \pm 5.6 a$ & $33.0 \pm 4.0 b$ \\
\hline
\end{tabular}

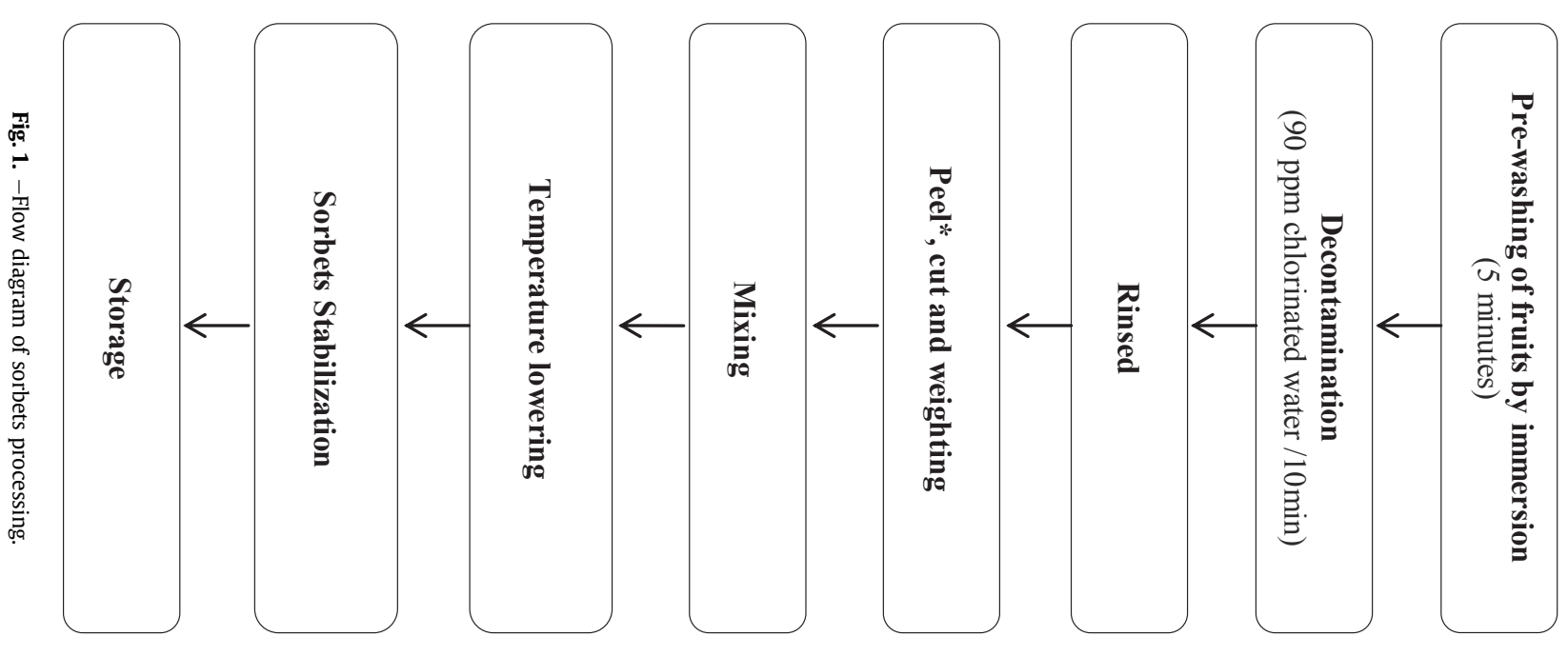

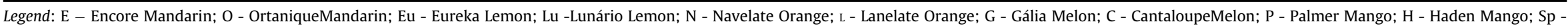
SpanishStrawberry; Pt - Portuguese Strawberry. In the same line, for each two fruits (cultivars or origins) different letters represent significant differences at $p<0.05$ (Scheffe test). 
Table 2

Sensory Classifications of fruits by expert panel.

\begin{tabular}{lllllll}
\hline & FA & FT & At & BT & ST & AST \\
\hline $\mathrm{E}$ & $2.5 \pm 0.6 a$ & $2.5 \pm 0.6 a$ & $1.3 \pm 0.5 a$ & $1.0 \pm 0.0 a$ & $2.7 \pm 0.5 a$ & $1.0 \pm 0.0 a$ \\
$\mathrm{O}$ & $3.0 \pm 0.8 a$ & $3.0 \pm 0.8 a$ & $2.3 \pm 1.3 a$ & $1.5 \pm 0.6 a$ & $3.5 \pm 0.8 b$ & $1.5 \pm 0.6 a$ \\
$\mathrm{Eu}$ & $3.8 \pm 1.7 a$ & $3.8 \pm 1.7 a$ & $3.5 \pm 1.0 a$ & $1.0 \pm 0.0 a$ & $2.3 \pm 1.5 a$ & $1.0 \pm 0.0 a$ \\
$\mathrm{Lu}$ & $3.0 \pm 0.0 a$ & $3.0 \pm 0.0 a$ & $5.5 \pm 0.6 a$ & $1.0 \pm 0.0 a$ & $1.5 \pm 1.0 a$ & $1.0 \pm 0.0 a$ \\
$\mathrm{~N}$ & $2.8 \pm 0.5 a$ & $2.8 \pm 0.5 a$ & $1.5 \pm 1.0 a$ & $1.3 \pm 0.5 a$ & $3.5 \pm 0.6 a$ & $1.3 \pm 0.5 a$ \\
$\mathrm{~L}$ & $2.5 \pm 0.6 a$ & $2.5 \pm 0.6 a$ & $1.8 \pm 1.0 a$ & $1.3 \pm 0.5 a$ & $2.5 \pm 0.6 a$ & $1.3 \pm 0.5 a$ \\
$\mathrm{G}$ & $2.8 \pm 1.0 a$ & $2.8 \pm 1.0 a$ & $1.3 \pm 0.5 a$ & $1.0 \pm 0.0 a$ & $4.0 \pm 0.8 a$ & $1.0 \pm 0.0 a$ \\
$\mathrm{C}$ & $3.5 \pm 1.3 a$ & $3.5 \pm 1.3 a$ & $1.3 \pm 0.5 a$ & $1.0 \pm 0.0 a$ & $3.0 \pm 1.2 a$ & $1.0 \pm 0.0 a$ \\
$\mathrm{P}$ & $4.5 \pm 1.3 a$ & $4.5 \pm 1.3 a$ & $2.0 \pm 0.8 a$ & $1.0 \pm 0.0 a$ & $5.0 \pm 0.8 a$ & $1.0 \pm 0.0 a$ \\
$\mathrm{H}$ & $2.5 \pm 0.6 b$ & $2.5 \pm 0.6 b$ & $2.8 \pm 1.3 a$ & $1.0 \pm 0.0 a$ & $2.5 \pm 1.0 b$ & $1.0 \pm 0.0 a$ \\
$\mathrm{Sp}$ & $3.8 \pm 1.0 a$ & $3.8 \pm 1.0 a$ & $2.8 \pm 1.5 a$ & $1.0 \pm 0.0 a$ & $3.0 \pm 1.4 a$ & $1.0 \pm 0.0 a$ \\
$\mathrm{Pt}$ & $4.5 \pm 1.3 a$ & $4.5 \pm 1.3 a$ & $4.5 \pm 0.6 a$ & $1.0 \pm 0.0 a$ & $4.3 \pm 1.0 a$ & $1.0 \pm 0.0 a$ \\
\hline
\end{tabular}

Legend: E - Encore Mandarin; O - Ortanique Mandarin; Eu - Eureka Lemon; Lu -Lunário Lemon; N - Navelate Orange; L - Lanelate Orange; G - Gália Melon; C Cantaloupe Melon; P - Palmer Mango; H - Haden Mango; Sp - Spanish Strawberry; $\mathrm{Pt}$ - Portuguatese Strawberry. In the same column, for each two fruits (cultivars or origins) different letters represent significant differences at $p<0.05$ (Friedmen test).

as explained for TPC. After taking an aliquot of the supernatant $(150 \mu \mathrm{L})$, it is mixed with $2850 \mu \mathrm{L}$ of DPPH diary solution. This mixture was then placed in the dark over $40 \mathrm{~min}$, after which the absorbance at $517 \mathrm{~nm}$ was measured (Unicam, UV/Vis Spectrometer - UV4. The measurements were performed in triplicate. From the values of absorbance, the Radical Scavenging Activity (RSA) was measured, expressed in percentage, Eq. (1).

$\operatorname{RSA}(\%)=[($ A initial - A final $) / A$ initial $) * 100]$

A calibration curve using Trolox (Sigma Aldrich) as standard was established, in order to convert the values of RSA to Trolox (M). To perform this curve, Trolox solutions with $50 \mu \mathrm{M}, 100 \mu \mathrm{M}, 200 \mu \mathrm{M}$, $300 \mu \mathrm{M}, 400 \mu \mathrm{M}, 500 \mu \mathrm{M}, 600 \mu \mathrm{M}$ and $800 \mu \mathrm{M}$ were prepared, which were made to react with the DPPH radical in the same conditions as the samples. The final results of antioxidant activity of the compounds are expressed as Trolox Equivalent Antioxidant Capacity (TEAC) Eq. (2), defined as the antioxidant capacity of the sample, relative to $1 \mu \mathrm{mol}$ basis of Trolox (Berg et al., 1999). Thus, as higher the TEAC value, higher is the sample's antioxidant activity.

TEAC $=\mu \mathrm{mol}$ Trolox $/ 100 \mathrm{~g}$ of fruit

\subsection{Sensory analyses}

Sensory evaluation of fruits and sorbets was assessed by an expert panel of 4 trained assessors (ISO 8586:2012). Sensory descriptive analysis was performed to characterized samples (fruits and sorbets). The first phase of training consisted in the language development followed by evaluation of samples in selected attributes: intensity of fruit aroma (FA), intensity of taste (Fruit taste TF, acid taste - AT, bitter taste - BT, sweet taste - ST) and astringency (AST). Ratings were based on a seven-point numerical unipolar category scale (0- absent, 1 - rather weak, 2 - weak, 3- moderate, 4strong, 5- rather strong, 6 very strong). The samples were presented to assessors monadicaly.

A hedonic analysis was performed by 20 consumers of sorbets, usual costumers of the industry. A six-point hedonic scale (1dislike very much, 2-dislike moderately, 3-dislike slightly, 4- like slightly, 5-like moderately, 6-like very much) was used to evaluate the degree of liking of the products. The neutral response category ("neither like nor dislike") was not included in the scale with the intention, in the case of a neutral sensation, to force the consumers for a positive or negative evaluation of sample. The consumers were also asked about the intention of buy the products. Purchase intention was evaluated in a four-point scale (1- certainly not purchase, 2- maybe not purchase, 3- maybe purchase, 4- certainly purchase).

Fruits for the sensorial analysis were at environmental temperature and the sorbets were at $13 \pm 1^{\circ} \mathrm{C}$.

\subsection{Statistical analyses}

Data from the analytical trials was subjected to analysis of variance (One-way ANOVA). Statistically significant differences $(\mathrm{p}<0.05)$ between samples were determined according to Scheffé test.

Sensory data from consumers were evaluated based on nonparametric tests. Friedman test was used firstly and a Wilcoxon test were used next to comparing two related samples t.

Multivariate analysis (Principal component analysis-PCA and Cluster analysis-CA) were applied to the sensory attributes to obtain an overview of the fruit effect on the sorbets quality.

All the statistical analysis was carried out using the software Statistica ${ }^{\mathrm{TM}}$.7 from Statsoft (StatSoft Inc., 2007).

Table 3

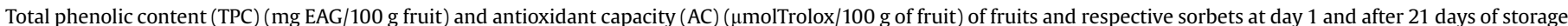
at $-18{ }^{\circ} \mathrm{C}$.

\begin{tabular}{|c|c|c|c|c|c|c|}
\hline & \multicolumn{3}{|l|}{ TPC } & \multicolumn{3}{|l|}{$A C$} \\
\hline & Fruit & $\mathrm{S} 1$ & S21 & Fruit & S1 & $\mathrm{S} 21$ \\
\hline E & $198.0 \pm 14.4 a$ & $110.1 \pm 6.2 b$ & $105.6 \pm 5.3 b$ & $336.7 \pm 51.7 a$ & $97.6 \pm 0.3 b$ & $97.4 \pm 0.4 b$ \\
\hline $\mathrm{O}$ & $195.5 \pm 21.5 a$ & $101.5 \pm 5.4 b$ & $112.6 \pm 12.7 b$ & $434.4 \pm 15.6 a$ & $99.1 \pm 0.9 b$ & $98.8 \pm 00.4 b$ \\
\hline Eu & $764.8 \pm 90.8 a$ & $69.7 \pm 3.7 b$ & $78.1 \pm 5.6 b$ & $591.0 \pm 17.9 a$ & $109.5 \pm 0.9 b$ & $109.7 \pm 0.8 b$ \\
\hline Lu & $675.6 \pm 30.4 a$ & $73.4 \pm 4.2 b$ & $71.4 \pm 1.7 b$ & $520.0 \pm 28.6 a$ & $111.5 \pm 1.1 b$ & $112.4 \pm 0.9 b$ \\
\hline $\mathrm{N}$ & $228.0 \pm 25.6 a$ & $129.2 \pm 9.9 b$ & $121.2 \pm 6.4 b$ & $736.0 \pm 102.0 a$ & $100.6 \pm 7.3 b$ & $102.1 \pm 0.3 b$ \\
\hline $\mathrm{L}$ & $236.1 \pm 6.8 a$ & $126.2 \pm 7.6 b$ & $107.4 \pm 7.1 b$ & $656.8 \pm 90.9 a$ & $102.9 \pm 3.3 b$ & $103.7 \pm 0.3 b$ \\
\hline G & $55.0 \pm 6.4 a$ & $23.4 \pm 4.6 b$ & $27.3 \pm 0.8 b$ & $87.5 \pm 14.6 a$ & $109.7 \pm 0.3 b$ & $109.2 \pm 0.2 b$ \\
\hline $\mathrm{C}$ & $52.9 \pm 8.1 a$ & $38.5 \pm 1.4 b$ & $37.5 \pm 2.0 b$ & $100.9 \pm 14.2 a$ & $83.1 \pm 0.6 b$ & $82.2 \pm 0.6 b$ \\
\hline $\mathrm{P}$ & $810.7 \pm 28.2 a$ & $95.2 \pm 5.1 b$ & $71.3 \pm 6.2 b$ & $693.9 \pm 48.3 a$ & $91.5 \pm 0.2 b$ & $92.0 \pm 0.6 b$ \\
\hline $\mathrm{H}$ & $712.4 \pm 115.5 a$ & $97.9 \pm 28.0 b$ & $67.0 \pm 6.2 b$ & $633.5 \pm 11.4 a$ & $95.2 \pm 0.1 b$ & $94.4 \pm 0.3 b$ \\
\hline Sp & $1043.0 \pm 44.4 a$ & $373.2 \pm 56.7 b$ & $316.0 \pm 20.9 b$ & $877.0 \pm 18.0 a$ & $46.5 \pm 0.6 b$ & $46.3 \pm 0.7 b$ \\
\hline $\mathrm{Pt}$ & $1014.3 \pm 32.9 a$ & $404.8 \pm 25.6 b$ & $294.7 \pm 61.2 b$ & $897.5 \pm 2.8 a$ & $49.1 \pm 1.0 b$ & $50.0 \pm 0.9 b$ \\
\hline
\end{tabular}

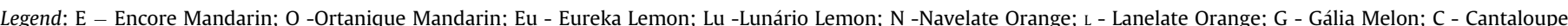

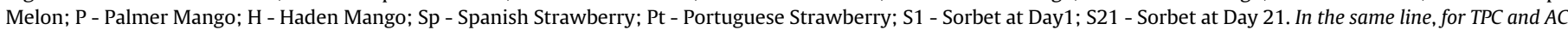
different letters represent significant differences at $p<0.05$ (Scheffe test). 

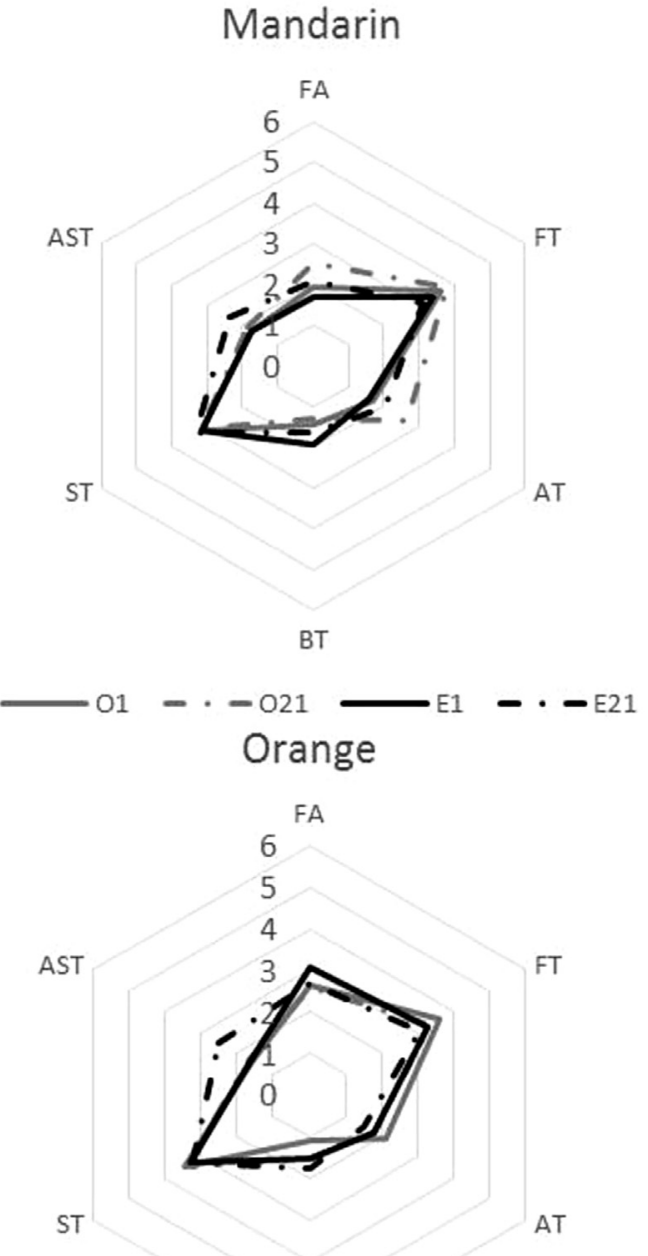

BT

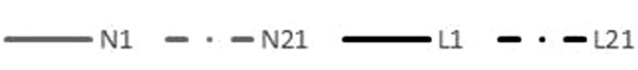

Mango

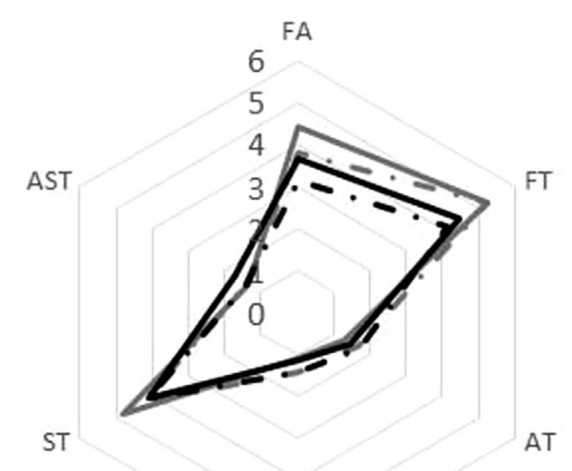

BT

\section{Lemon}

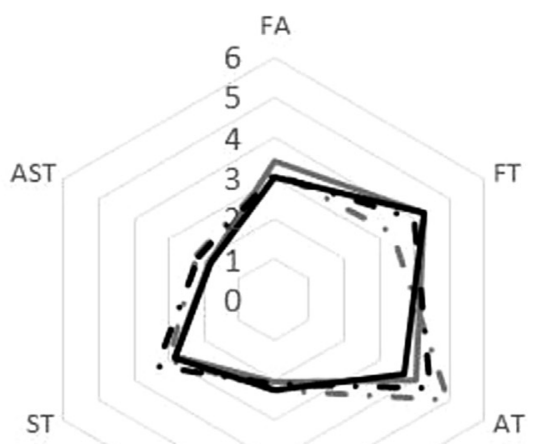

BT

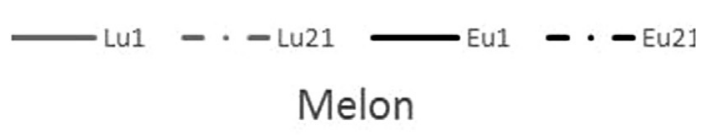

AST

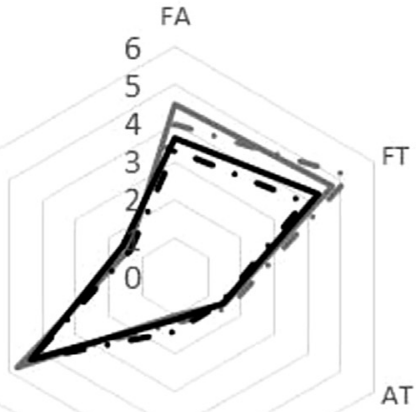

BT

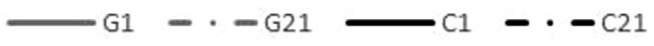

\section{Strawberry}

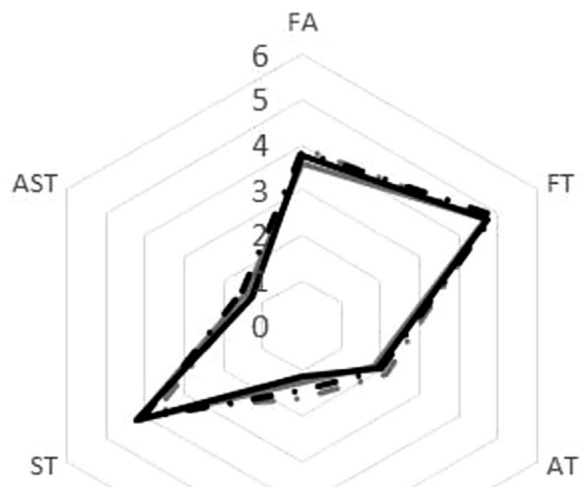

AT

BT

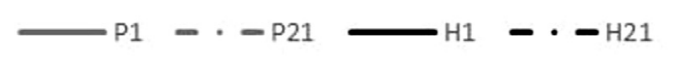

$\longrightarrow$ Pt1

Pt1 - - Pt21

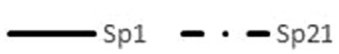

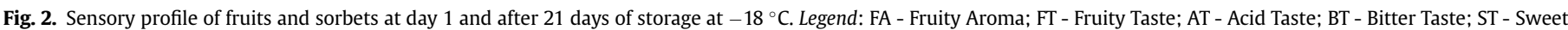

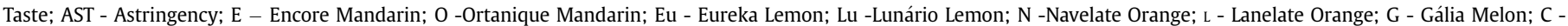
Cantaloupe Melon; P - Palmer Mango; H - Haden Mango; Sp - Spanish Strawberry; Pt - Portuguese Strawberry; 1 - Sorbet at Day1; 21 - Sorbet at Day 21. 

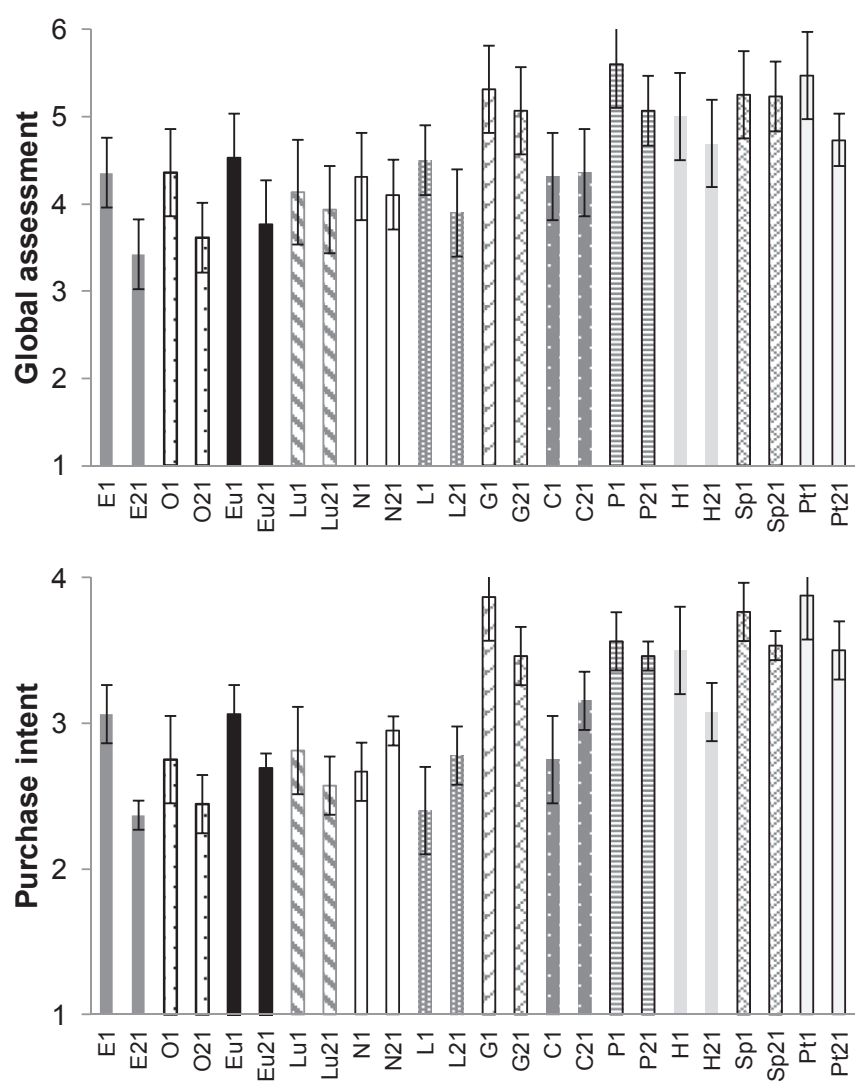

Fig. 3. Global assessment and purchase intent of sorbets at day 1 at day 1 and after 21 days of storage at $-18{ }^{\circ} \mathrm{C}$. Legend: E - Encore Mandarin; O -Ortanique Mandarin; Eu Eureka Lemon; Lu -Lunário Lemon; N -Navelate Orange; L - Lanelate Orange; G - Gália Melon; C - Cantaloupe Melon; P - Palmer Mango; H - Haden Mango; Sp - Spanish Strawberry; Pt - Portuguese Strawberry; 1 - Sorbet at Day1; 21 - Sorbet at Day 21.

\section{Results \& discussion}

\subsection{Characterization of the fruits}

\subsubsection{Physical-chemical characterization}

The physical-chemical characterization of fruits used as raw materials for the sorbets production is presented in Table 1.

The results show that fruits from different cultivars or origins are different regarding the physical and chemical parameters that most influence the sensory characteristics: TSS, TA and colour parameter ${ }^{\circ}$ h. Although lemons showed a quite similarity in all analysed parameters.

Most chemical parameters (acidity, TSS, firmness and peel and pulp colour - ${ }^{\circ} \mathrm{h}$ ) of the Encore and Ortanique mandarins are significantly different being Ortaniques sweeter and more acid. The results are not in agreement with Roussos, Paziodimou, and Kafkaletou (2011) who concluded that most of the chemical parameters of Encore were similar to those of the Ortanique fruits. This can be explained by different cultural practices, including fertilization as well as soil and climate conditions.

Lunário lemons exhibit a significant different colour parameters of pulp and peel. Peel hue angle is lower than the one reported to Siciliano cultivar in colour-break stage, characterized by the loss of the green colour (Jacomino, Mendonça, \& Kluge, 2003). Hue angle and $\mathrm{pH}$ of Lunário fresh pulp are in accordance to those found on 'Lisbon' lemons by Artés-Hernández, Rivera-Cabrera, \& Kader, 2007.

Navelate and Lanelate oranges exhibit the same acidity, but significantly different TSS, being Navelate oranges sweeter. The colour of the both orange cultivars (for peel and pulp) exhibit no significant differences $(\mathrm{p}<0.05)$. It was observed that the values of peel hue are similar to the ones described by Arpaia (2008) for the same varieties. Current results for Lanelate $\mathrm{pH}$ are similar to Washington Navel cultivar and the TSS is equivalent to the New Hall and closer to Washington Navel fruits, while Navelate orange's TSS and $\mathrm{pH}$ are higher (Roussos et al., 2011). Navelate fruits exhibit a high phenolic content and a high AC.

Regarding melons, the main difference between both cultivars is the pulp and peel colour. As expected, hue angle is significantly different. Cantaloupe fruits exhibit an orange pulp, characterized by a high content of carotenoids, which justified the slightly higher AC, despite the lower TPC. Nevertheless, TPC and AC exhibited no significant $(\mathrm{p}<0.05)$ differences in both fruits. It was also verified that Cantaloupe melon is sweeter than Gália and shows less acidity and moisture. Based on the TA, pH, firmness and TSS, it was noted that Gália melons were near the minimum levels of acceptance (10 ${ }^{\circ}$ Brix) (Morais, 2009), suggesting that the ripeness stage of fruits would not be the most suitable for sorbets production.
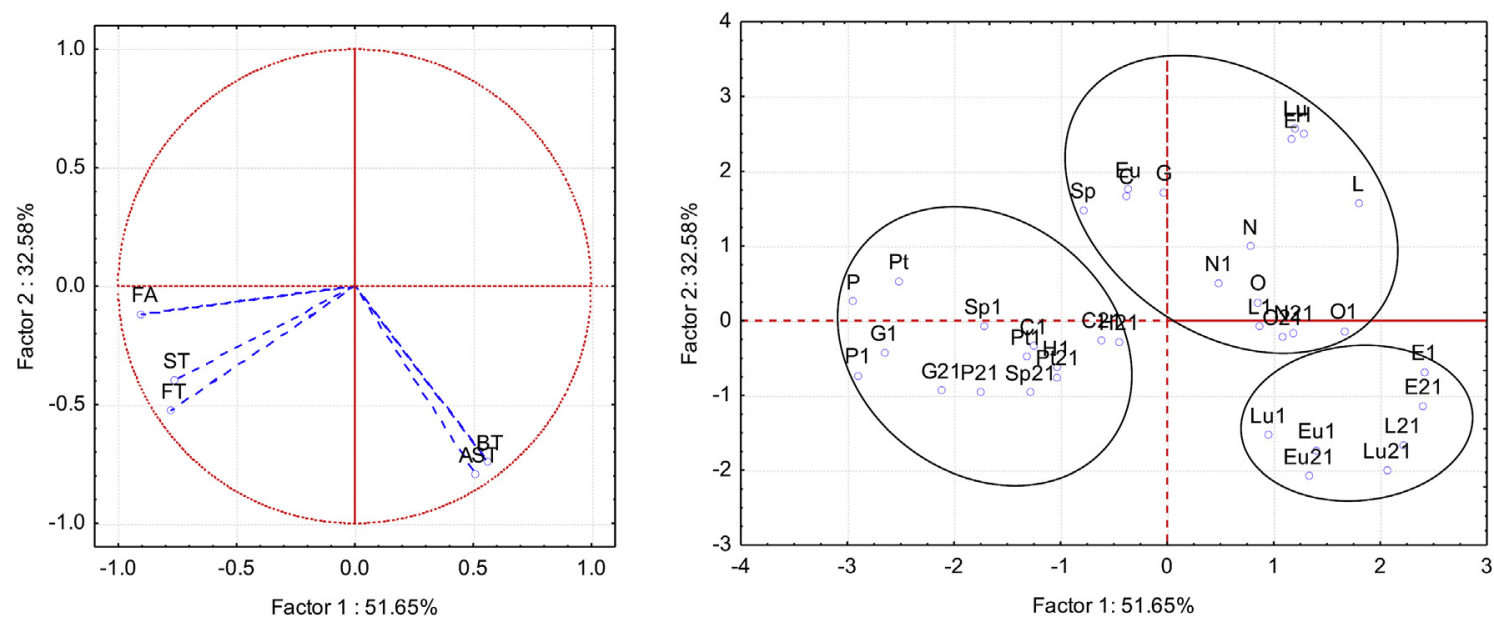

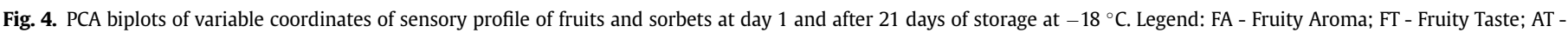

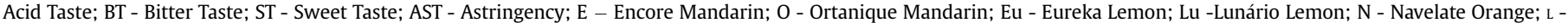

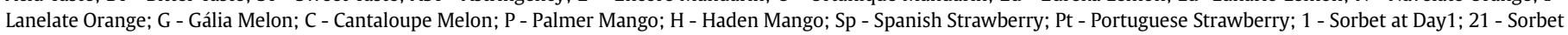
at Day 21. 
Mango cultivars are significantly different in the studied parameters. Palmer mango is sweeter and less acid. Haden TSS/AT is similar to Kent varieties (Okoth et al., 2013). AC of both cultivars was in accordance with Percival et al., 2006, whereas TPC was higher than the ones reported. It is important to be mentioned that both cultivars exhibited signs of a correct mature stage at the harvesting. Palmer and Haden showed significantly different pulp colours $(p<0.05)$, the Palmer being more orange and Haden slightly yellow which is in conformity with Bender, Brecht, Sargent, \& Huber, 2000.

According to Table 1, the TSS, pH, firmness and colour of pulp and peel of strawberries from two origins are significantly different $(\mathrm{p}<0.05)$.The Portuguese strawberries are harder and sweeter. The TSS of Portuguese strawberries are in good agreement with Antunes, Ristow, Krolow, Carpenedo, \& Júnior, 2010.The TSS of Spanish strawberries are comparable to Galexia (Antunes et al., 2010) and Camino Real cultivar (Pineli, Moretti, \& Chiarello, 2012). Even though the present results the $\mathrm{pH}$ values are in good agreement with Kafkas, Kosar, Paydas, Kafkas, \& Baser, 2007 and Antunes et al., 2010, for Portuguese strawberries and Spanish fruits they were comparable to Osogrande cultivars (Pineli et al., 2012). The parameters of colour are significantly different $(p<0.05)$, due to the more intense red colour presented by Portuguese fruits, with a hue angle nearest to zero (red), in accordance with Wszelaki \& Mitcham, 2000. Firmness and TA of both origins are also in good agreement with the same author.

\subsection{Sensory evaluation}

Table 2 shows the evaluation of the different fruits, in the selected attributes, by the expert assessors. According to analysis, no significant difference $(\mathrm{p}<0.05)$ were found on sensory attributes of lemon, orange, melon and strawberry fruits from different cultivars or origin for all the attributes tested. In what concerns mandarin, the Ortanique cultivar is significantly sweeter then Encore, what is in agreement with the chemical characterization ( $15^{\circ} \mathrm{Brix}$ and $12{ }^{\circ} \mathrm{Brix}$ respectively). Palmer mangos are more aromatic, with a more pronounced fruit taste, and sweeter than Haden mangos.

\subsection{Characterization of sorbets at day 1 and after 21 days of storage at $-18^{\circ} \mathrm{C}$}

\subsubsection{Total phenolic content and antioxidant capacity}

According to Table 3 processing fruits into sorbets leads to a loss of TPC, being this fact more pronounced in mango and lemon $(\approx 90 \%)$ and strawberry (60-65\%). The other fruits registered a loss about of $50 \%$ of the phenolic content. In general, no significant $(p<0.05)$ changes were noticed in sorbets along the 21 days of storage. Consequently, a similar behaviour was observed for antioxidant capacity.

\subsection{Sensory analysis}

Fig. 2 shows the sensory profile of fruits and sorbet at day 1 and after 21 days of storage at $-18{ }^{\circ} \mathrm{C}$. In general, the sensory profile of sorbets are very similar to the one of the fruit used as raw material. This pattern is quite prominent in strawberry sorbets were no differences were noted also after 21 days of storage at $-18{ }^{\circ} \mathrm{C}$.

After storage, citric sorbets from Encore mandarin and Lanelate orange showed a slightly increase of the astringency. Galia melon and Palmer mango showed to be varieties that allowed the production of more aromatic sorbets.

Based on consumers evaluation (Fig. 3) all the tested sorbets were well accepted after processing (day 1) showing average ratings up to 4 . Melon, mango and strawberry sorbets were well classified with average ratings above 5 . Citrus sorbets were not so well accepted by consumers mainly due to the astringency and acidic taste. Few variations were noted, in sorbets acceptance, along the storage time, with exception of the mandarin sorbets that presented a notorious decrease of its classifications. Overall, different cultivar or origins did not influence the global assessment and purchase intention of sorbets. Just for the melon sorbets these differences are noticed, being the Gália sorbets the best classified ones.

\subsection{Principal component analysis}

According to PCA analysis the two first principal components (PC1 and PC2) accounted for $84 \%$ of total variability (Fig. 4.). PC1 is related to fruit aroma, fruit taste and sweet taste while PC2 is explained by the bitter taste and astringency.

Cluster analysis shows that three homogeneous clusters are formed at a Euclidian linkage distance of 5 . One cluster gather lemon fruit and respective sorbets and is mainly related with the bitter taste and astringency characteristics which justified the worse acceptance of these sorbets. Mangos and strawberries, as well as respective sorbets plus melon sorbets, form another cluster related, with fruit aroma and taste and sweet taste. Mandarins and oranges and respective sorbets formed a dispersed cluster that also includes the melons, of more undefined characteristics.

Multivariate analysis allows to verifiy that the sorbets produced by Santini maintain quite similar sensorial characteristics regardless the cultivar or origin of the fruits and are quite stable during 21 days of storage at $-18^{\circ} \mathrm{C}$.

\section{Conclusions}

It was possible to conclude that fruits cultivar or origin does not influence sensory characteristics of sorbets in a significant way over 21 days of storage. The exception is sorbets from the encore mandarins that show a significant decrease on global assessment and purchase intent after 21 days stored at $-18^{\circ} \mathrm{C}$. It was also observed that processing fruits leads to a loss of TPC and AC. Nevertheless, no significant changes were seen over storage time.

\section{Acknowledgements}

The authors acknowledge the Santini Lda for providing all the materials to support this project. Financed by Fundação para a Ciência e Tecnologia (PEst-OE/AGR/UI0245/2014).

\section{References}

Aguayo, E., Escalona, V. H., \& Artés, F. (2004). Metabolic behavior and quality changes of whole and fresh processed melon. Journal of Food Science, 69 $148-155$.

Antunes, J. E. C. Ristow, N. C., Krolow, A. C. R. Carpenedo, S. \& Júnior, C. R. (2010). Yield and quality of strawberry cultivars. Horticultura Brasileira, 28, 222-226.

Arellano, M., Benkhelifa, H., Flick, D., \& Alvarez, G. (2012). Online ice crystal size measurements during sorbet freezing by means of the focused beam reflectance measurement (FBRM) technology. Influence of operating conditions. Journal of Food Engineering, 113, 351-359.

Arpaia, M. L. (2008). Harvest and evaluation of strain trials at Lindcove Research and Extension Center. Citrus Research Board, 2008 Annual Report.

Artés-Hernández, F., Rivera-Cabrera, F., \& Kader, A. A. (2007). Quality retention and potential shelf-life of fresh-cut lemons as affected by cut type and temperature. Postharvest Biology and Technology, 43, 245-254.

Bender, R. J., Brecht, J. K., Sargent, S. A., \& Huber, D. J. (2000). Mango tolerance to Reduce oxygen levels in controlled atmosphere storage. Journal of the American Society for Horticultural Science, 125(6), 707-713.

Botia, P., Navarro, J. M., Cerdá, A., \& Martınez, V. (2005). Yield and fruit quality of two melon cultivars irrigated with saline water at different stages of development. European Journal of Agronomy, 23, 243-253.

Brand-Wiliams, W., Cuvelier, M. E., \& Berset, C. (1995). Use of a free radical method 
to evaluate antioxidant activity. Food Science and Technology, 28, 25-30.

Corvitto, A. (2005). I Segreti del gelato. Gelato senza segreti. Barcelona: Vilbo edicionaes y publicidad, ISBN 84-922443-4-8 (Chapter 16).

Goff, H. D., \& Hartel, R. W. (2013). Ice cream (7th ed.). New York: Springer Science+Business, ISBN 978-1-4614-6095-4 (Chapter 2).

Hunt, R. W. G. (2004). The reproduction of Colour (7th ed.). New jersey: Wiley, ISBN 978-0470-024270.

ISO 750. (1998). Fruit and vegetable products. Determination of titratable acidity. Genève, Switzerland: International Organization for Standardization.

ISO 8586. (2014). Sensory analysis - General guidelines for the selection, training and monitoring of selected assessors and expert sensory assessors. Genève, Switzerland: International Organization for Standardization.

Jacomino, A. P., Mendonça, K., \& Kluge, R. A. (2003). Armazenamento refrigerado de limões 'Siciliano' tratados com etileno. Revista Brasileira de Fruticultura, 25(1), $45-48$.

Kader, A. A. (1985). Postharvest biology and technology: an overview. In A. Kader et al. (Eds.), Postharvest technology of Horticultural crops (pp. 39-47). California: UC DANR. ISBN 1-879906-51-1 39-47.

Kafkas, E., Kosar, M., Paydas, S., Kafkas, S., \& Baser, K. H. C. (2007). Quality characteristics of strawberry genotypes at different maturation stages. Food Chemistry. $100,1229-1236$

Kim, Y., Lounds-Singleton, A. J., \& Talcott, S. T. (2009). Antioxidant phytochemical and quality changes associated with hot water immersion treatment of mangoes (Mangifera indica L.). Food Chemistry, 115, 989-993.

Lester, G. (2006). Environmental regulation of human health nutrients (ascorbic acid, b-carotene, and folic acid) in fruits and vegetables. HortScience, 41, 3-7.

Markowski, J., Zbrzezniak, M., Mieszczakowska-Frac, M., Rutkowski, K., \& Popinska, W. (2012). Effect of cultivar and fruit storage on basic composition of clear and cloudy pear juices. LWT - Food Science and Technology, 49, 263-266.

Morais, P. L. D. (2009). - Avaliação das tecnologias pós-colheita utilizadas e da qualidade de melões nobres produzidos para exportação. Ciência e Tecnologia dos Alimentos, 29(1), 214-218.

Ngamchuachit, P., Sivertsen, H. K., Mitcham, E. J., \& Barrett, D. M. (2015). Influence of cultivar and ripeness stage at the time of fresh-cut processing on instrumental and sensory qualities of fresh-cut mangos. Postharvest Biology and Technology, $106,11-20$

Okoth, E. M., Sila, D. N., Onyango, C. A., Owino, W. O., Musyimi, S. M., \& Mathooko, F. M. (2013). Evaluation of chemical and nutritional quality attributes of selected mango varieties at three stages of ripeness, grown in lower Eastern province of Kenya - part 2. Journal of Animal \& Plant Science, 17(3), 2616-2619.

Percival, S. S., Talcott, S. T., Chin, S. T., Mallak, A. C., Lounds-Singleton, A., \& PettitMoore, J. (2006). Neoplastic transformation of BALB/3T3 cells and cell cycle of HL-60 cells are inhibited by mango (Mangifera indica L.) Juice and mango Juice extracts. The Journal of Nutrition, 136(5), 1300-1304.

Pineli, L. L. O., Moretti, C. L., \& Chiarello, M. D. (2012). Quality, bioactive compounds and antioxidant activity of strawberries grown in the Brazilian savannah and stored at different temperatures. Journal of Food, Agriculture \& Environment, 10(2), 165-171.

Roussos, P. A., Paziodimou, C., \& Kafkaletou, M. (2011). Assessment of twenty two citrus cultivars (oranges, mandarins and lemons) for quality characteristics and phytochemical's concentration. ISHS Acta Horticulturae, 981, 657-663.

Sahin, S., \& Sumnu, S. G. (2006). Physical properties of foods. New York: Springer Science+Business, ISBN 978-0387-30780-0.

Shin, Y., Ryu, J. A., Liu, R. H., Nock, J. F., \& Watkins, C. B. (2008). Harvest maturity, storage temperature and relative humidity affect fruit quality, antioxidant contents and activity, and inhibition of cell proliferation of strawberry fruit. Postharvest Biology and Technology, 49(2), 201-209.

Simón-Grao, S., Gimeno, V., Simón, I., Lidón, V., Nieves, M., Balal, R. M., Carbonell-Barrachina, A. A., Manera, F. J., Hernández, Fca., \& García-Sánchez, F. (2014). Fruit quality characterization of eleven commercial mandarin cultivars in Spain. Scientia Horticulturae, 165, 274-280.

StatSoft Inc. (2007). STATISTICA (data analysis software system). version 7. Tulsa, USA.

Sturm, K., Koron, D., \& Stampar, F. (2003). The composition of fruit of different strawberry varieties depending on maturity stage. Food Chemistry, 83(3), $417-422$.

Swain, T., \& Hillis, W. E. (1959). The phenolic content of Prunus domestica. I. - the quantitative analyses of phenolic constituents. Journal of the Science of Food and Agriculture, 10(1), 63-65.

Tulipani, S., Marzban, G., Herndl, A., Laimer, M., Mezzetti, B., \& Battino, M. (2011). Influence of environmental and genetic factors on health related compounds in strawberry. Food Chemistry, 124(3), 906-913.

Wszelaki, A. L., \& Mitcham, E. J. (2000). Effects of superatmospheric oxygen on strawberry fruit quality an decay. Postharvest Biology and Technology, 20, 125-123. 